\title{
Several Thoughts on Current Development of College Students
}

\section{Counselor's Work}

\author{
Yu He \\ School of Music, Dezhou University, Dezhou 253023, China \\ E-mail: dzxynxx@sina.com
}

Received: December 31, $2010 \quad$ Accepted: January 20, 2011 doi:10.5539/ach.v3n2p55

\begin{abstract}
As part of college teacher team and a worker at the first line of college ideological and political education, college students counselor should update the education philosophy in the new era, confirm the role position, meet the needs of social development, change the method of work according to work conditions, explore new innovative work mechanism, and promote the fast and comprehensive development of college students counselor's work.

Keywords: College students' counselor, Role position, Problems and reasons restricting the development, Countermeasures

An explanation of counselor's basic tasks from Encyclopedia of China ------ Education is: educate students ideologically and politically and make it work. College students' counselor, as part of college teacher team and a worker at the first line of college ideological and political education, is playing a critical role in strengthening college students' ideological and political education. In the new era, the building of counselor team and the work process are confronted by many restricting problems. Under this circumstance, college students' counselor should be capable of analyzing new situations and finding new problems, keep in improving self qualities, confirm the role position, and dedicate to the grand mission of cultivating the socialist builders and successors with ideas, morals, knowledge, and disciplines.
\end{abstract}

\section{The brief development history of college students' counselor}

In the year 1952, the state proposed a political counselor at college. In 1953, Tsinghua University and Peking University applied the Ministry of Education for pilot. Afterwards, many colleges and universities established the counselor system and regulated that the counselor was to be students" "political guide" and mainly for political education. In the $21^{\text {st }}$ century, the Communist Party pays more attentions to ideological and political education work. In 2000 and 2004, two papers are issued respectively in order to promote the work of college students' ideological and political education, especially the No.16 Paper, which extends the functions of counselor, adding the function of "helping students to solve practical problems" into the paper, and guarantees counselors with more benefits and development.

\section{The position of college students' counselor team (the role in a macro perspective)}

The No.16 $6^{\text {th }}$ Paper points out that: "The work team for ideological and political education is an organizational guaranty for strengthening and improving college students' ideological and political education. The principal party of the work team is communist cadres and Communist Youth League cadres, courses of ideological and political theories, philosophy and social science teachers, counselors, and class teachers." "Counselors and class teachers are the backbone of college students' ideological and political education. Counselors do what the Party asks to carry out the ideological and political education activities. Class teachers are responsible for guiding students with ideology, study, and life."

Thus, in addition to being "the backbone of ideological and political education", the counselor team now has new positioning: (1) Professional counselors are one part of teachers. (2) Counselors are the directors and guiders who are responsible for the healthy growth of college students.

\section{The position of college students' counselor (the role in a micro perspective)}

After preliminary research, concise the core business of counselor, enhance the effectiveness of counselor's ideological and political education, improve counselor's specialties in counseling, and divide the work of 
counselor into three part: ideological and political education, class management, and consulting services.

\section{The work features of college students' counselor in a new era}

The coming of the $21^{\text {st }}$ century presents higher requirements for the quality of talents, which makes higher education draw wide attentions inevitably. Colleges and universities are the base for cultivating talents. The ideological and political education in colleges and universities becomes the key for talents output. Therefore, the CPC Central Committee and the State Council propose the "Advices on Further Strengthening and Improving College Students' Minds and Political Education", which mentions that the work team for ideological and political education is the organizational guaranty for strengthening and improving college students' ideological and political education. The effective ideological and political education serves as an important guaranty for cultivating college students with good personalities, excellent characters, aggressive and innovative spirits. College students' counselor, as the worker at the front of moral education, should recognize current problems, understand self responsibilities, improve the work, and complete the mission of the time. However, some problems restrict the innovation and development.

\subsection{Problems in the building of counselor team and relevant reasons}

Problems in the building of counselor team

4.1.1 Inflexible work mechanism and unreasonable personnel structure. Counselors contact directly with students. They are responsible for students' ideological education, political cultivation, and daily routine activities. As a counselor, he or she should consider the entire situation of the school. But as a class teacher, he or she should protect the interests of the class. Therefore, conflicts are inevitable. Sorts of contradictories and conflicts in the work mechanism not only constrain the building of counselor team, but also affect the innovation of students management work.

4.1.2 Narrow range of knowledge, wide work fields, and weak penetration power. Counselors are engaged in daily business for a long time. They do not have much time for learning. As a result, they fail to master new knowledge and technology in time. They can not provide the most effective guidance for students, which may weaken their influences and cohesion.

For these problems above, we can focus on the following points to improve the quality of counselor team.

(1) Emphasize on the building of counselor team and set up relevant work mechanism.

Colleges and universities should take the building of counselor team as an important part of the building of teacher team and management team, and carry out the "Regulations for the Building of Counselor Team in Common Colleges and Universities". According to the "Regulations", colleges and universities should make the building of counselor team parallel with the teaching activities and the building of scientific research team, planning and directing it with a long-term wisdom. Constitute specific ways for examining the work of counselors, and improve the examining system for counselor team. Organize counselors to study and discuss periodically, learning from the discussion, progressing from the learning, carrying out from the practice, and finally improving the quality of counselors.

(2) Carefully select the qualified professional counselors and thoroughly improve the quality of counselor team.

College Party committees and students Party organizations at all levels should establish the belief that "ideological and political education is also a science" and excellent counselors are valuable. College and universities should select and cultivate counselors by the way of selecting and cultivating the academic backbone. Completely get rid of the wrong opinion that "everyone could do what a counselor does". Colleges and universities should carefully develop and train, and bravely select and employ the excellent young talents who have better political quality, strong senses of responsibilities, and are good at ideological and political work, improving the entire quality of counselor team.

(3) Take effective measures to optimize the counselor management system and delete the worries of counselors.

First of all, set up a series of supervisory and assessment mechanism right for the work of counselors. As a part of college teachers, counselors should be guaranteed with positions, functions, employment, and job classification in the system. Secondly, colleges and universities should offer various trainings for counselors considering the requirements of the times, what can help counselors to adapt to social development, update the knowledge, and work as qualified moral guiders. Thirdly, care about counselors from their political treatments, work conditions, and living state. The saying goes, "workers with happy family work better". If relevant departments in colleges and universities can really improve counselors' life physically and spiritually, they would be more pleasant to associate self development with moral education work. 


\subsection{Problems in work}

In addition the problems in the building of counselor team, there are some new problems in the new era.

4.2.1 Problems from changes of social, political, and economic environment.

In China, along with the deepening reform and opening up policy, the coming of knowledge economy times, and the entry of WTO, people's living environment and living views change significantly. (1) The upsurge of knowledge economy. It makes the competition between countries more severe. And the competition is to compete for talents and education in a great degree. Under the complex circumstance, colleges and universities, as the base for cultivating highly-qualified talents, should guide students in specialties, minds, and activities, which is meaningful for improving the whole quality of students, solving the problem of lacking talents, and ensuring the quantity and quality of talents. (2) The negative influences of market economy. Along with the fast development of market economy and the deep execution of reform and opening up, college students know well the society, acquire more knowledge, and expand their vision. However, some unhealthy ideas also penetrate into the colleges and universities, seriously impacting the formation of healthy ideas, values, and behaviors. As a result, college students may lose life pursuits and beliefs, and feel confusion about moral values, employment, and future fate. Besides, they are not interested in their majors, lacking of aggressive spirits or disciplines, without the collective consciousness. They pay too much attention on profits over sincerity. They are self centered, without the spirit of dedication or the spirit of collectiveness. The ideological and political education in colleges and universities at the special times is urgent. (3) The impact of Internet. Due to the fast progresses of the information times and the popularization of network, as amounts of students absorb information in the new era, some corrupted life styles, and wrong views generate strong impacts on them. Although college students are capable of distinguishing the right from the wrong to certain degree, they can not keep cool and calm all the time. Therefore, some college students become "network addicts". Their lives are dominated by the Internet, forgetting the study and self-development. Similar cases are in a rising state. Relevant departments, especially the counselors at the front of college moral education, should pay necessary attention to this fact.

\subsubsection{Problems caused by the reform of higher education system}

The reform of higher education system tends to be marketization. Since the expansion of college enrollment in 1999, college education gradually shifts from the elite education to mass education. On one hand, it is good for the improvement of the quality of citizens. On the other hand, the enrollment continues to expand, which will inevitably challenge the quality of college students. Therefore, in the new situation, counselors will face new challenges since they have to provide guidance for students considering their different qualities, and bases. At the same time, due to the continuous increase of students, the proportion of counselors to students is out of balance. As a result, counselors have to burry themselves in numerous businesses. They can not know all students' ideological conditions in time, so that they fail to play their roles in work thoroughly. Besides, because of the reform of higher education charges, some changes happen concerning the role of students. In many students' opinion, they buy education with money. What the college should provide is not only management but the services. So, they request more self rights. This kind of opinions is popular. Counselors should pay close attention to this problem, and change ideas at the right time, in order to do a better job.

\subsubsection{Problems caused by changes of college students}

Today, most college students are the only child born in late $80 \mathrm{~s}$ in $20^{\text {th }}$ century. They enjoy excessive love from parents, and are incapable of dealing with difficulties independently or self management. They are self-centered and never care about or consider others. As a result, it affects their study and school life, which adds more difficulties into the management of college students. Secondly, today's college students have a strong sense of superiority. Although they have distinctive personalities and active thoughts, their psychological minds are still immature. Some students may feel frustrated once they are confronted with troubles in study and life. Caring for college students' psychological pressure and teaching them to learn how to adjust themselves and release pressures become the most urgent task for the work of student management in a new era. Thirdly, the interaction of people change, and the love issue turns into an integral part of counselors' work. It is more important to help college students dealing with emotional problems. Repression and restrictions are improper in the new era. Counselors should give college students positive guidance, and help them to build up the right values of love and life.

Considering these problems, we should overcome various difficulties under the new situation in the new era, improve the ideological and political education work from these following aspects.

(1) Confirm the role of counselor 
The work of counselor is directly associated with the success of ideological and political education. Only by means of confirming the role of counselor, can we accomplish the work properly. To be a good counselor, the first is to know the role of counselor in colleges and universities. In Dec. 1995, the Ministry of Education issued the "Outline for Common College Moral Education in China (Trial)". It says: Counselors are professional political workers for students, that is, workers who professionally provide ideological and political education for students. Counselors, together with "ideological and political teachers", are professional moral teachers. Therefore, we notice that counselors are grassroots cadres who are engaged in college students' ideological and political education. They are the "backbone" of entire ideological and political education and the professionals in the field. As for the nature of counselors, they are not administrators but teachers. They shoulder an important mission of shaping college students' minds and morals. Counselors should be instructors: guiding students to complete the study smoothly, directing them to be involve in positive activities physically and spiritually, helping them to solve psychological problems and develop good daily habits, guiding them to achieve a full development of morals, intelligence, sports, and aesthetics, and helping them to prepare for graduation and start of careers. In a word, we should confirm the role of counselor and make sure that counselors are engaged in cultivating socialist builders and successors with hopes, morals, knowledge, and disciplines.

(2) Improve the self quality of counselor

To improve the self quality is the precondition and the base for make innovations as a counselor. College student counselors should behave as moral representatives and restrict themselves severely. On one hand, build noble characters, strengthen the morals, set up good self images, care for and protect students in dedicated work attitudes, and educate students with their words and activities, enhancing the effectiveness of ideological and political education. On the other hand, considering the fast development of knowledge economy, counselors should possess rich knowledge, experiences, and theories. They must continue to update the specialty knowledge in order to communicate with students effectively. Besides, they have to be familiar with the knowledge in fields of sociology, psychology, education, computer and network. Therefore, counselors should not only continue to improve the knowledge accumulation, arm and enrich themselves with scientific theories, but also possess the most exciting enthusiasm for work, adopt the most effective ways, making progresses along with the times, and conveying the new ideas, knowledge, and information to students by modern educational ways.

The new century is facing new opportunities and new challenges. In front of all kinds of mutual conflicts of thoughts and cultures, every ideological and political educator should actively explore the new thoughts and ways for the work of counselors. Fulfill the spirit of "making progresses along with the times", under the guidance of scientific development view, and create a nice phenomenon for student management, increasing the effectiveness of the work. Seek truth from facts and study new conditions with passions. Create new ways for effectively managing students and explore a new condition for college ideological and political education.

\section{References}

A Learning Assistant Book of "CPC Central Committee and State Council's Advices on Further Strengthening and Improving College Students' Minds and Political Education". Beijing: China Renmin University Press.

Pan, Min. (1996). New Explorations on First-Class College Students' Cultivation (Cases Collection). Shanghai: Shanghai Jiaotong University Press.

Qi, Luliang. (2005). On the building of college students counselor team. Journal of Hunan University of Arts and Science: Social Science Edition.

$\mathrm{Xu}$, Caiqian. (2004). How to do better as a college students counselor in a new era. Journal of Huaiyin Institute of Technology.

Zhao, Hui. (2007). On the work innovation of college students counselor in a new era. Industrial \& Science Tribune. 